\title{
The Market Totem: Mana, Money and Morality In LATE Modernity
}

\author{
JAMES F. Cosgrave
}

Abstract. Durkheim was concerned with the anomie generated by a social order too strongly oriented to economic activity and the pursuit of wealth. His last book, The Elementary Forms of Religious Life, is an exploration of the social basis of knowledge and moral authority, but also prospectively links economic life to its religious sources and to "mana." Despite his sociological-moral concerns with diminished moral authority in an emerging industrial, market society, The Elementary Forms of Religious Life provides an analytical framework from which to analyze the totemic nature of stock and financial markets. While contemporary financial markets reveal dangers for solidarity, and demonstrate the continuing relevance of Durkheim's sociological-moral concerns, the analysis of "the market" offers an opportunity to extend the Durkheimian interest in emerging totemic entities and forms of the sacred.

Keywords: markets, totems, wealth, morality, sacred

Résumé. Durkheim était préoccupé par l'anomie générée par un ordre social trop orienté vers l'activité économique et la quête de la richesse. Son dernier ouvrage, Les formes élémentaires de la vie religieuse, est une exploration de la base sociale du savoir et de l'autorité morale mais lie aussi prospectivement la vie économique à ses sources religieuses et à la «manne.» Malgré ses soucis sociologico-moraux concernant la diminution de l'autorité morale dans une société de marché industrielle en devenir, Les formes élémentaires de la vie religieuse procure un cadre analytique à l'étude de la nature totémique de la bourse et des marchés financiers. Alors que les marchés financiers contemporains révèlent des dangers pour la solidarité et démontrent la pertinence actuelle des inquiétudes sociologico-morales de Durkheim, l'analyse du «marché» offre l'occasion d'étendre l'intérêt Durkheimien pour les entités totémiques émergentes et pour les formes du sacré.

Mots clés: marchés, totems, richesse, moralité, sacré 
There was another marked resemblance between the events of 1929 and those of 1987. That was the prompt search for a scapegoat on which the stock market collapse, however inherent in the previous speculation, could be blamed. Economic theology is here involved. The market is not only perfect but in some measure sacred. For its own internal dynamic and resulting disaster it cannot be held responsible. (John Kenneth Galbraith 1988: xvi).

The Bourse, international stock exchanges, are extremely anxious moral persons... (Marcel Mauss 1924: 644)

\section{INTRODUCTION}

In September 2008, as a consequence of the subprime mortgage crisis and the collapse of investment bank Lehman Brothers, a rescue package ("Troubled Asset Relief Program" - TARP) was created to ensure that, not just American, but global financial markets could continue to function. When then US Treasury Secretary Henry ("Hank") Paulson and other officials concocted the original "bailout" package, who could say what amount of monetary relief would suffice? The package should be big enough to restore "confidence" in credit markets, and $\$ 700$ billion was produced as a figure that would stimulate lending. The response to the market crisis demonstrated the moral commitments, not to mention the near-panic and last minute negotiations of state officials - the emotional actions, oriented to getting the financial system moving again. The system was haemorrhaging, clottage was occurring, and circulation needed to be restored.

The market crisis and the responses to it demonstrated the collective investment in, and a paying of tributes to, the sacralized global financial markets. Certainly there were, and continue to be, serious political criticisms (and protests) of the bailout of Wall Street financial institutions. Nevertheless, some firms that faced financial disaster (such as American International Group) were deemed "too big to fail," and the actions then to restore the markets, and the ongoing political and economic actions oriented to saving highly indebted countries and the banks that own their debt, mark and display the sacred and totemic features of late modern global stock and financial markets explored here. The term late modern designates a socio-historical development whereby markets have 
emerged as institutions of central global institutional significance, accompanied by financialization and their socio-cultural effects. ${ }^{1}$

The totemic features of markets are discussed drawing upon the work of Emile Durkheim, in particular, his final work The Elementary Forms of Religious Life (hereafter EFRL). EFRL theorizes the social grounds of moral authority and ideals, and poses the question of the religious basis of economic actions and institutions (Durkheim 1995; Steiner 2008); it thus also provides an analytical framework for understanding the emergence and sacralization of stock and financial markets. For Durkheim, sacredness constitutes social solidarity. Sacredness is the determinant aspect of the "totemic principle" through which people, things, places, animals, and symbols are constituted in group form and seen as belonging together (Durkheim 1995: 190-191). All human thought, action and organization is rooted in, and is an expression of, a force of solidarity and cohesion within a grouping, the most basic manifestation of which is religion - the simplest religious grouping being the totemic group: "totemism is not the religion of certain animals, certain men, or certain images; it is the religion of a kind of anonymous and impersonal force that is identifiable in each of these beings but identical to none of them" (Durkheim 1995: 191).

Totemism depends upon representation, and the (impersonal) force of representation: groups exist through, and are subject to, their "collective representations" (Durkheim 1984, 1995). These representations are the basis of moral authority and endow particular objects, people, rites, and feelings, with sacredness. The realm of sacred objects is collectively organized as distinct from the profane, that which pertains not to the special moral authority and collective power of a group, but to the purview of individual persons. The distinction between the sacred and the profane itself is an organizing principle of human thought (Durkheim 1995). Thought, action, and organization are thereby collective products in as much as they develop in the context of group life and refer to the power of the group or "mana." Mana is an impersonal force, a diffuse power imbuing objects with sacredness, the source of which is collective life itself (EFRL: 190-206).

As emergent sacralized phenomena, markets can be analyzed in terms of their totemically-organized, socio-historical conditions of possibility. This discussion thus contributes to a diachronic understanding of

1. Financialization refers to the increase of financial market products and the seeking out of profits based on the creation and use of such products. It also refers to the increasing power of investment banks (such as Goldman Sachs) in economies and the displacing of manufacturing by finance in relation to the generation of GDP value. See e.g., Krippner (2005), Marazzi (2010). 
totems and their historical emergence and decline (Datta 2007). Markets are conceived here sociologically as grounded in, and generative of, collective "ways of acting, thinking, and feeling" (Durkheim 1984: 51) that are the characteristic material of social life.

Outside of economic sociology, the language and analysis of modern financial markets has not much considered the impact of collectivity on its workings. This is largely due to the dominance of mainstream economics and its approach to understanding the constitution of markets, with its rationalistic and individualizing conceptions: rational choice or action, the efficient market hypothesis, "homo economicus," and the like (Fama 1970; Fox 2011). The events of 2008 and their ongoing destructive economic consequences have contributed to criticisms of economics, and furthered self-criticism within the discipline as well, since most economists not only failed to predict these events, but have been unable to provide solutions. ${ }^{2}$ The self-criticism relates to questions of methodology and conceptions of the economic actor, as the abstract and reifying mathematical models favoured by the discipline are coming to be viewed as unable to explain real life actions, despite their "aesthetic beauty" (Basen 2011; Nelson 2006). Critics of the rationalistic economic conceptions have sought to incorporate the place of emotions (Galbraith 1988; Shiller 2000) and "animal spirits" - a term from economist John Maynard Keynes - into market analysis, giving rise to alternative orientations, such as behavioural economics (Akerlof and Shiller 2009; Thaler 1993). The latter emphasizes the psychology of individual actors. This article, by contrast, develops a Durkheimian sociological approach to markets.

There are a variety of ways the nation-state/capitalist market relationship can be organized (Pearce and Tombs 1998): this discussion focuses broadly on stock and financial markets as they have emerged historically to become totemic entities that organize collective life. The term "the market" is used commonly in business and finance talk, connoting an entity having "external and coercive" characteristics (Durkheim 1984). Further, for some, "the market" is a highly valorized ideal that should be deferred to for economic decisions, and is even seen as a source of knowledge and wisdom (Friedman 1962; Ailon 2012). This sacralized conception is central to neoliberal economic ideology. Notwithstanding variations in the state/market relationship, late modern markets are valorized as "mana" (Durkheim 1995: 421). However, such markets also

2. In response to Queen Elizabeth's question about why no one saw the credit crisis coming, some influential British economists produced a report that blamed, among other things, "a failure of the collective imagination of many bright people" (Stewart 2009). 
bring with them dangers for solidarity. The discussion begins with Durkheim's economic sociology and its formulation of danger.

\section{Durkheim's Economic Sociology and Economic Anomie}

While Durkheim is considered one of the founders of economic sociology, along with Max Weber (Steiner 2008; Swedberg and Granovetter 2011: xv), he is not often drawn upon in the analysis of late modern financial markets and money. Durkheim distanced himself from economics when he was developing his "science of society," perceiving in the whole field serious methodological problems (Steiner 2008: 7-17). His founding insights stressing the role of social structures and "social facts" in shaping economic action, have contributed greatly to the critique of conventional economics' conception of the atomized and self-interested economic agent (Durkheim 1982; Slater and Tonkiss 2001; Steiner 2008; Swedberg and Granovetter 2011).

Contemporary critiques of economics methodology (e.g. Akerloff and Shiller 2009) echo Durkheim's (1886) criticisms of over a century ago. Nevertheless, despite his importance for economic sociology, Durkheim-inspired analyses of late modern, capitalist markets are rare. ${ }^{3}$ Swedberg and Granovetter (2011: xv) note that, in contrast to Weber (for whom economics was one of his "major professional interests"), Durkheim was more interested in the social phenomena of morality, religion and education. However, Durkheim's sociological interests in religion and knowledge, explored in EFRL, offer a way of thinking about the place of economy in society: economic life can be approached through analyses of the religious grounds of moral authority, the social grounds of classification, and the collective force of mana (Durkheim 1995; Steiner 2008). Moral authority is a sociological preoccupation throughout all of Durkheim's work. Thus, if in The Division of Labour in Society (1964), the modern economy is situated within, and regulated by, the division of labour and the (organic) bond of relational interdependence, Durkheim's writings on economic anomie (Durkheim 1966, 1973, 1992) revealed his fears, and a moral perspective, that the generalized pursuit of wealth, made possible by the development of modern industry, would have negative social consequences. Durkheim did not write specifically on money (while Marx, Weber, Simmel, ${ }^{4}$ and Durkheim's followers Mauss (1914) and Simiand (1934) did), but rather on the morally deregulating con-

3. See Tognato (2007). Preda's Framing Finance (2009) offers occasional insights inspired by Durkheim's EFRL.

4. For a discussion of the sociology of money classics, see Deflem (2003). 
sequences of wealth. Indeed, for Durkheim, a social order capable of constraining desire was paramount:

...it is because morality has the function of limiting and containing that too much wealth so easily becomes a source of immorality. Through the power wealth confers on us, it actually diminishes the power of things to oppose us. Consequently, it lends strength to our desires and makes it harder to hold them in check... Thus, we can understand the nature and source of this malady of infiniteness which torments our age. (Durkheim 1973: 43)

In Professional Ethics and Civic Morals, Durkheim contends that the "amoral character of economic life amounts to a public danger" (1994: 12). Durkheim's sociological-moral concerns of over a century ago appear highly relevant in the context of financial events of the last few decades: the contemporary dangers will be discussed in a later section.

\section{Modern Markets and the Durkheimian Dilemma}

Despite their complexity and significance for the collective-economic life of modern societies, stock and financial markets are conceived as constituted by, or outcomes of, the actions of (rational) individuals (Slater and Tonkiss 2001: 6-35; Preda 2009: 8; Swedberg 2010). In contrast to an economic-individualistic understanding, we could ask in a Durkheimian vein: How are markets collective representations, i.e., totemic entities expressing the sacralised aspirations, beliefs, and values of those in late modern capitalistic economies? What is the nature of the relationship between markets and social solidarity?

Perhaps Durkheim is not drawn upon in the analysis of markets because he is viewed as not "modern" enough — compared to Simmel for example, who saw money as an historical-cultural object and preoccupation of modern society (Simmel 1978). Similar to Durkheim's concerns with the immorality of wealth, Simmel saw money as the "profaner" and formulated its alienating propensities (Simmel 1978). More positively than Durkheim however, Simmel saw the "impersonality" of money producing forms of interconnectedness and sociation (even if traditional forms of solidarity were breaking down), and instituting and supporting the modern values of freedom and independence (Simmel 1978, 1997). Significantly, " $(\mathrm{t})$ he pinnacle of this development is represented by the joint-stock company" (Simmel 1997: 245). Simmel was thus less defensive about the trajectory of modern morality, although "the permeation 
and objectification of...monetarized exchange (was) a mixed blessing" (Slater and Tonkiss 2001: 81).

It is possible to read Durkheim as a cusp theorist: articulating the framework or solidarity of the society of his time, but portending the dangers of an emerging society whose values would be markedly different from his own. The dangers of economic anomie were already present for Durkheim: "The functions of the (economic) order today absorb the energies of the greater part of the nation. The lives of a host of individuals are passed in the industrial and commercial sphere. Hence, it follows that, as those in the milieu have only a faint impress of morality, the greater part of their existence is divorced from any moral influence" (Durkheim 1994: 12).

In contrast to his sociological contemporaries (i.e., Simmel and Weber), Durkheim's moral views are quite divergent, particularly since the latter half of the nineteenth century witnessed the increasing social legitimacy of stock markets and speculation, the development of the "science of the market" and conceptions of the functions of stock markets and their positive contributions to society (Preda 2009). Indeed, much like the biological metaphors in Durkheim's own "science of society" (Durkheim 1984) and the analogy of society as organism (the latter a powerful concept in late nineteenth century natural and social science), stock markets too came to be conceived as analogous to biological entities:

What matters is to explain the function fulfilled by markets in the society at large. A functionalist explanation, however, has to be supplemented by an adequate market model. Biological analogies and functionalist explanations did not exclude recourse to statistics. Quite the contrary: it was the analogy with biology which justified the application of statistics to economic and financial phenomena. (Preda 2009: 102)

Durkheim's concerns about economic anomie can be counter-posed to the emerging respectability and legitimacy of markets and speculation as construed in hegemonic economics discourses. One might think that the emerging "science of the market" would have garnered approval from Durkheim, since a rigorously Durkheimian economic science would be pursued by Francois Simiand (Steiner 2008). One year after Durkheim's publication of The Division of Labour in Society, Max Weber published articles on the stock and commodity exchanges (Weber 2000a, 2000b). While Weber was concerned with the "fever symptoms" that could be generated by open access to financial investments and stock exchanges (Preda 2009: 43), he also admired the "monopoly of the rich" and the system of honour that informed their market activities and reputations 
(Preda 2009: 44). In certain respects, Durkheim's moral concerns seem to have more in common with the negative views of stock trading and speculation of the eighteenth century, when these were associated with gambling, the expression of devilish interests and "dark powers" (Preda 2009: 84-85).

It is difficult, then, to reconcile the emerging dominance of economic institutions in modernity with pervasive pathology: Durkheim was able to see the rise of the individual and its accompanying morality in organic solidarity, but the expansion and centrality of economic institutions could only signify moral deregulation. Durkheim's conception of "[a] nomie can be identified only as a negation of morality, not as an alternative to a prevailing system of morality; this means that anomie does not have an autonomous identity, but exists only as a lack of moral status, a defamation of the ideal standard" (Orru 1987: 113). While Durkheim criticized economic thinking for removing all things social from human life, and offered occupational groups as a solution to the perils of economic anomie (Durkheim 1992; Cladis 2005; Steiner 2008; Swedberg and Granovetter 2011), the gap between a dominant institution and a lack of moral undergirding persists as a theoretical problem. For an analyst of social morphology and emergent institutions, how could it be that widespread social pathology exists and persists?

Robert Merton offered one response to the Durkheimian dilemma. In Merton's (1968) well-known reformulation of anomie in his "strain theory" of deviance, nowhere is "economic anomie" referred to, only "anomie." In the context in which Merton is writing (mid-twentieth century American society), wealth is a "cultural goal" and sacrosanct: "in our competitive society...wealth has taken on a highly symbolic cast" (Merton 1968: 195). While Merton is aware of "institutionally dubious innovations" in the pursuit of success, it is the "sacrosanct goal that virtually consecrates the means" (Merton 1968: 196). Certainly, the differences in cultural and historical context are to be noted, but the Mertonian framework acknowledges the institutionalizing of wealth as a "sacred" object. ${ }^{5}$ Durkheim did, however, offer that the society of his time was "going through a period of transition" and that "the former gods are growing old or dying, and others have not been born" (EFRL: 429) .

In terms of the chronology of Durkheim's work, but thought about in relation to the idea of the increasing marketization of society (Slater and Tonkiss 2001), Durkheim appeared to work in reverse. His earliest work was his most "economic," The Division of Labour in Society now con-

5. In the American context Merton's discussion of wealth was influenced in part by Veblen: Merton's notions of manifest and latent functions drew from Veblen's (1899) analyses of wealth and status emulation (Tilman 2007: 233). 
sidered one of the founding texts of economic sociology (Steiner 2008; Swedberg and Granovetter 2011: xv). His last work, EFRL, is considered the least concerned with the economy, or at least any concern with economy is well hidden behind the dominant analytical concerns with religion, the social, and knowledge. However, Steiner (2008) makes clear that Durkheim's analysis of religion in EFRL was a prospective link to the sociology of economic life. In the book's conclusion, Durkheim states that "...we can say that nearly all the great social institutions were born in religion" (EFRL: 421). Following this statement, in a footnote, a brief discussion of economy appears:

Only one form of social activity has not as yet been explicitly linked to religion: economic activity...economic value is a sort of power or efficacy, and we know the religious origins of the idea of power. Since mana can be conferred by wealth, wealth itself has some. From this we can see that the idea of economic value and that of religious value cannot be unrelated; but the nature of these relationships has not been studied. (Durkheim 1995:

421)

It is significant for the sociology of knowledge that $E F R L$ was published in 1912, seven years after Weber's The Protestant Ethic and the Spirit of Capitalism (published in two parts in 1904 and 1905) and twelve years after Simmel's The Philosophy of Money, which Durkheim had the occasion to review, mostly negatively. ${ }^{6}$ Durkheim's text on "religious life" (but of course, much more than this) thus appears after two of the classic sociological analyses of the development of the modern capitalistic economy and money.

As Orru writes, "[i]n later works, like Moral Education and The Elementary Forms of the Religious Life, the word anomie disappears, but the concern with moral order and the search for a solution to the pathological absence of moral norms in modern society is more explicit than in Durkheim's previous works" (1987: 108). Clearly, Durkheim had not changed his mind about the moral weakness of modern society as his work developed. However, despite his moral criticisms of the modern economic order, Durkheim's EFRL provides a framework for analyzing emerging sacred and totemic phenomena of modern life, like stock and financial markets. Where Durkheim posed the question of the religious origins of economy, a theme addressed in the work of Marcel Mauss (Steiner 2008), EFRL also prompts the question pursued here:

6. Emile Durkheim, 1980. Georg Simmel. Philosophie des Geldes. In Emile Durkheim: Contributions to L'Année Sociologique, edited by Y. Nandan, 95-98. New York/London: Free Press/Collier Macmillan. 
How could the importance of mana in the social not be reconstituted for an increasingly secular, economically-oriented society?

\section{The Emerging Market Totem}

As a totemic entity, "the market" is depicted in economic discourse as greater than all the individuals who participate in it, collectively representing their financial investments but also their emotional ones: their hopes, dreams, and fears, their concerns about the present and also of the future. As "a reality sui generis" (Preda 2009: 54), financial markets are founded on the social facts of money and circulation (Mauss 1925; Simiand 1934) in that markets provide representational spaces to "think with" money; made visible through various technologies and actions (discussed below), they also collectively represent the valorization of wealth as mana.

As representational spaces, stock and financial markets represent money (on stock tickers, screens, etc.), and hence are communicative spaces that generate action oriented to these representations. As a symbolic representation of all the things it can be exchanged for, and embedded in social processes of circulation, money is totemic (Mauss 1925; Simiand 1934). In representing money as numbers on screens, markets further the abstraction of money from the things it symbolically represents, in and through exchange. But this abstraction does not mean there is no emotional attachment, "effervescence," or rituals, since symbols are the source of emotional intensity (Durkheim 1995: 221; Knorr Cetina and Bruegger 2002). Markets thus simultaneously abstract and sacralize money. This sacralization is evidenced and performed through the representational (and technological) constitution of markets organized to depict monetary values. Money is given positive moral valence through its totemic representations. Markets thus collectively represent the actions of the group oriented to (its) mana.

The rise to institutional prominence of stock and financial markets in late modern societies is the tale of emergent social phenomena over the last four hundred years. Interestingly, within capitalism, stock trading, and later the stock market, had to come to be seen as legitimate and a source of positive morality: the market's totemic status is the product and outcome of social, economic, and technological developments (Fabian 1990; Preda 2009). And capitalism itself had to overcome the pre-modern social and religious ethics that held the explicit pursuit of wealth as a lowly, i.e., sinful and corrupting activity: as Weber (1958) argues, the pursuit of wealth had to be supported by legitimating social 
ethics. Adam Smith's (1776) notion of the "invisible hand of the market" is notable, not just as a legitimating account of early capitalism but for its totemic characterisation; the market is represented as an entity that guides by and through invisible yet powerful forces, embodying an unseen rationality. ${ }^{7}$ Whatever other characteristics are said to define social groups at the time, "the market" becomes a collective representation expressing "the way in which the group thinks in its relationships with the objects which affect it" (Durkheim 1982: 40). Further, for Smith, the analysis of the market was related to the "wealth of nations" (Smith 1776; Preda 2009). Not only is wealth represented as a desirable object for individuals and collectivities, it is tied to a burgeoning nationalism as ground for the power of the (national) group. In Smith's account, it is the manufacturer who holds central status in the market, contributing to the social good through industry, guided by knowledge, skill and innovation. The speculator is "the antipode of the manufacturer," and thus capitalism's “nemesis" (Preda 2009: 33). It would take another century for the speculator to emerge as an acceptable market actor, and for speculation to be judged a legitimate, but also useful form of economic activity (Preda 2009: 82-112).

The development of a closed and bounded arena for stock trading has been crucial for the development of "the market" as an objectified totemic entity. Market sacralization has thus contributed to cognitive and emotional orientations (such as speculation), which will be discussed in the next section. Significantly, this sacralization has also generated a distinction, or "sacred" separation between the valorized beliefs and activities that support it, and other realms, such as government, which can be found in liberalism. Stock trading in the eighteenth century, which took place in the streets and in coffee houses, gave way to the technological and rationalized organization of trading in enclosed exchanges (Preda 2009: 52-81). Technological developments have been crucial in building "the market," and as expressions and consequences of social action, have themselves been guided by actor orientations to "markets" — the buying and selling of stocks and a need to see, and be informed about stock prices. Technologies, such as the stock ticker (Preda 2009), embody forms of knowledge and ways of seeing that come to represent and express a "market" consciousness. Such developments are objectivations of this consciousness; the ticker made the market "visible as a faceless whole" and served as a system for representing events in the

7. Comte's and Spencer's views that social phenomena are governed by natural laws also contribute to this type of thinking. Following his predecessors, Durkheim's emphasis on "social facts" exemplifies this notion of hidden, powerful social forces. 
world (Preda 2009: 128-129). The imbued authority of the stock ticker and the social conflicts that stemmed from its value for market participants (Preda 2009: 138-141) suggest that the ticker not only begins to reorganize market actions in particular ways, but becomes a totemic object for this group. It becomes a form of "churinga": a totemic object used in group rituals (Durkheim 1995: 118-122). The churinga is totemic because it bears the emblems or markings of the group and is thus handled (and stored) with sacred care; the stock ticker displays the movement of prices which are emblems of the market, and guides varieties of social action: monitoring the ticker, reflection on price movements, reporting on prices, buying and selling stocks, and stock analysis. The emblems on the stock ticker (prices) are numerical and in motion: we can thus reflect on the ways in which numbers are an instituted collective representation (prices, statistics, and other numerical values used by the collective) and indeed Durkheim treated statistics (e.g., in Suicide) as such. According to Steiner (2008: 156), the quantitative sociology being developed in the work of Durkheim's followers, Mauss and Simiand, saw "in statistics a means for grasping the group in motion." The statistic is then, among other things, a collective representation of a dynamic type of collectivity. ${ }^{8}$

What about the motion of numbers on the stock ticker? Is the motion itself a collective representation of life in modernity, related to other phenomena, such as the "news" and its constant reporting? The increased volume and velocity of numbers, and the expansion of their screened representations into a variety of public and private spaces has been a consequence of the computerization of markets and trading since the 1970s. Stock market index and high profile stock (e.g. Apple or IBM) movements are reported daily in business news programs, further embedding markets in everyday life. The daily coverage ritually sacralizes market movements as (always) news. The movement of numbers offers another representation of the modern interest in novelty (Simmel 1971; Benjamin 1996), and also a burgeoning example of, and interest in, "action" (Goffman 1967). Thus, in contrast to the early forms of totemism (Durkheim 1995), where the totem appears to the group to be static, some forms of late modern totem are dynamic (Thrift 2005). The market thus represents the institutionalizing of the movement of (monetary) values: lack of movement ("clottage") would be a sign of the profane.

8. Cormack (2002: 49) likens the statistic to a totemic object: “...like the totem, the statistic tells the story of how the collective organizes itself... The sociologist helps reinforce the taken-for-granted nature of this representation by uncritically imagining that it speaks directly about the phenomenon it measures, rather than about how the collective imagines itself to be statistical." 
According to Preda (2009: 130), "In 1884, with the stock ticker now a solid market feature, Dow Jones \& Co. began publishing average closing prices of active representative stocks, thus initiating the first stock market index." The invention of the ticker and the technology created to project prices onto screens shaped the "visual experience of the market," contributing to "cognitive organization" (Preda 2009: 136). This entailed cognitive preoccupation with stocks (prompted by the new visual orientation), but also emotional attachment to them, effectively binding actors to the marketplace (Preda 2009: 135-136).

A further development of market consciousness was the chart - a cognitive-technological object created to map price movements, which in further serving to objectify the "market," fostered "expert" analysis of price movements ("technical analysis"), including "price prophecies" (Preda 2009: 156). The chart adds another visual layer to the market (beyond the moving numbers on the ticker): it halts the numbers (prices), enabling them to be put in relation, thus allowing the detection of patterns. The chart produces "observation from afar" (Preda 2009: 146). It is a telescopic technology - a way of seeing the market, but also, as a technology of objectivation, further constituting the market as totemic. As technologies, the ticker and the chart do not just render a "market" visible - they are material objects that constitute or make markets: in embodying and representing the market they are market churinga. According to Preda (2009: 169): "technical analysis is different from particular transactions, yet intrinsic to market action. In truly Durkheimian fashion, it contributes to the creation (by witnessing) of a collective entity called 'the market,' irreducible to individual transactions."

On the one hand, the market becomes objectified and a source of representations (prices and other numerical data). On the other, as will be discussed, it prompts particular social actions, i.e., certain cognitive orientations and emotional responses. The market is then not only a source of representations, both numerical and discursive - the language of the market, the analysis of stocks, the price predictions, etc., it is a collective representation.

\section{Ways of Acting, Thinking, and Feeling the Market: Speculation AND CONFIDENCE}

Durkheim's sociological premise is that societies are moral orders, apprehensible scientifically as "social facts," which are "any way of acting, whether fixed or not, capable of exerting over the individual an external constraint" (Durkheim 1982: 59). This constraint is grounded in the 
"visible, tangible expression of an underlying, inner fact that is wholly ideal: moral authority" (Durkheim 1995: 210). ${ }^{9}$ The Elementary Forms extends the analysis of social facts first formulated methodologically in The Rules of Sociological Method (1982) and applied in Suicide (1966) (although the term is used only once in EFRL, in a footnote): the categories and concepts of thought are produced in the social as cognitivepractical phenomena (Durkheim 1995; Rawls 1996). Markets and their extenuating phenomena are external and coercive - not only in their practical effects on economic life and individuals' and groups' financial worth and life chances for example, but in the "ways of acting, thinking, and feeling" (Durkheim 1982, 51) they generate and manifest.

For all the emphasis on rationality and individualizing cognitive constructs by which markets have been represented, the totemic characteristics of markets - as late modern collective representation - signal sociological issues of identification and emotion. A construct such as the efficient market hypothesis (i.e., the market correctly reflects and values all available market information, the market is never wrong, etc.) implicitly, if not explicitly, represents the market as totemic, pointing to an entity (the market) that collects and processes actions and collectively represents them. However, among other criticisms, it is an overly rationalized construct that has treated market material (prices, etc.) and social actions (e.g., investing) as something like pure types. In other words, people (investors) are conceived as rational choice actors, thinking about and orienting to utility maximization, and market prices are expressions of this conception. Certainly, the effort to include emotions is important in the analysis of market actions. "Fear and greed" are staple emotion glosses on the "behaviour" of markets. If they do account for market emotions, it is on the basis of the collective valorizing of wealth (with which Durkheim was concerned). A sociological analysis of markets' totemic features however must account for the ways of acting, thinking, and feeling that are generated. Along with the emotional and ritual constitution of markets, the performative aspects must also be considered.

Speculation can be thought about in this way. While Smith (1776) saw wealth as a barometer of a nation's strength, in the late eighteenth century all speculation was bad speculation, either parasitic on the production of wealth, or incomprehensible and thus unable to be integrated into knowledge and the social order (Preda 2009: 84). A century later, speculation had largely overcome its previous stigma and is being formulated as a functional activity for society.

9. Durkheim's first formulation of religion (in 1899) conveys religion's links to moral obligation. See Durkheim (1975). 
The integration of speculation at the end of the nineteenth century, requires a differentiation between good and bad speculation, and thus, among other things, a distinction between good speculation (which is productive) and gambling (Fabian 1990; Preda 2009). Speculation is becoming subject to authoritative knowledge and is conceived as a rational activity, contributing to society. This shift requires "representations of the social and natural order in which to integrate financial speculation with its successful occurrences, as well as with its failures, representations supported by and emanating from...special financial knowledge" (Preda 2009: 173). Having a legitimate place in the activities of the stock exchange, it is thus integrated into the division of labour (Preda 2009: 183).

Speculation is conceived, on the one hand, as rational and functional (constituting its legitimacy and integration); but on the other it retains its emotional impetus, since it is a "natural force" and excess is intrinsic to it (Preda 2009: 181). The market is a "[c]ivilizing force and untamed natural force at the same time" (179), it contributes to society (the social organism) as a living, emotional force. In a Smithian vein, stock exchanges come to be seen as national symbols - indicating the wealth and economic power of cities and nations, centrally important as financial circulatory systems. In keeping with the biological metaphors of the time, they are viewed as organs "co-ordinating general social circulation," and speculation is a "vital force" (Preda 2009: 186).

Perhaps it was this force that prompted Durkheim's worry, the power of wealth to generate excesses and therefore anomie. However, the rise of speculation, the institutionalizing of stock exchanges, and the societal orientation to wealth signified by these developments, are indicative of wealth functioning as mana (Durkheim 1995). And this mana is a force oriented to by individuals and collectivities, as wealth itself becomes evidence and representation of power (Durkheim 1995: 421). Markets emerge as totemic entities since they collectively represent wealth as an object of collective investment: individuals participate through their investments - their financial participation and their emotional involvement signifies market investiture.

Speculative financial practices, as ways of thinking, feeling, and acting, have developed in relation to, and helped to constitute, the emergence of stock and financial markets as social practices. Certainly, there is a persistence of speculation stigma, especially evident since the events of 2008: it is "gambling," it produces nothing valuable, it is greedy, etc. This stigma derives in part from the persistence of "producerist" ideologies that conceive financial speculation as unproductive for society (Ramp and Badgley 2009). It is also found within market discourse that 
holds that speculative practices distort pricing processes and exacerbate risk. Nevertheless, speculation practices are forms of knowledge that enact or "perform" money. These practices orient to money as (potential) profit and in doing so find methods of representing and deriving it from itself (e.g., derivatives). While financial speculation has always been innovative - in terms of the creation of practices and products, such as the creation of margin, which dates back to the 1720s (Galbraith 1988; Muller 2002), but also in Merton's sense of "dubious" orientations, contemporary late modern speculation has been enabled by the computerization of markets, market specularization, and the development of sophisticated mathematical modeling techniques. Speculation in late modern markets has stimulated, and provides a salient example of, the interest in simulations (Baudrillard 1983).

The development of practices of speculation is ongoing and further represented in the rise of financial products and strategies (monetization of products, derivatives, hedging, etc.) that have accompanied the late modern financialization of economies (Krippner 2005; Marazzi 2011). These are ways of thinking the market totem, and depend precisely on the development of markets as objectified entities: speculation requires speculari: "to observe" (Bay 2012). Markets are representational entities and have become so through their technological constitutions: from stock tickers and visual screens, to charts and computer screens. Physical money becomes increasingly abstract as numerical representations on screens. It thus becomes idealized in markets: first, by its (ongoing) pursuit as a social value, and through the various ways it is attended to (emotionally, cognitively, visually, etc.) in market actions (Knorr Cetina and Bruegger 2002); secondly, as a representational phenomenon that has generated, not only these actions, but cognitive and technological innovations in its representational possibilities.

The objectivation of markets has as its corollary the use of mathematical modeling to render simulations of the actions of markets. As mentioned, the reifying of "markets" in these models has been criticized for their inability to account for real social actions (Akerloff and Shiller 2009; Basen 2011). A problem here is the representational confidence ascribed to the models: they claim verisimilitude, when they are better viewed as market performances (Mackenzie 2006). As performances they signify the life of the market totem, in other words, they attest to the power of the totem to generate forms of knowledge and help to enact it. It is not only the "animal spirits" that animate market actions but also the forms of knowledge that participate in its totemic life. As with the vital- 
istic conceptions of the late nineteenth century, emotion and knowledge are invested. ${ }^{10}$

Indeed, market actions, i.e., the actions of actors participating in the market, have come to be represented as emotional (e.g. fear or greed), and emotion has the power to override all "rationality" and knowledge: the market "panic" offers such an example, where fear (of financial loss) drives actions (Preda 2009). What is significant about market panics is that market actors do not have direct observational (face to face) access to one another to interpret emotional states (e.g., panicky behaviour). Their observations are technologically mediated, such as watching numbers on screens, and their understandings of what is occurring or has occurred in markets are mediated by the definitions provided by others - such as news reports that markets "panicked" (Preda 2009). The "investment" in the market here is shown with full force: the financial participation merges with the emotional responses, and the market is the representational entity (totem) that constitutes and collects the actor responses. However, if the clan rituals Durkheim (1995) discussed were enlivened by the physical co-presence of members, global markets lack such co-presence; they are mediatised and acted on and through, from anywhere. Thus, the market as totem represents a (potential) universalizing membership, beyond the particularities of nationality. Durkheim himself referred to the "universal market" (Durkheim 1964).

Durkheim theorized the emergence and development of "international groupings" as a logical consequence of religious life and the contact between tribes: "The more we advance in history, the larger and the more important these international groupings become" (Durkheim 1995: 428). ${ }^{11}$ While nation-states have their stock exchanges and national currencies (the eurozone being one example of the monetary transcending of such currencies), markets enable cross-border transactions and the intermingling of currencies bringing nations into increasingly global economic, social, and political relationships. However, national interests and state sovereignty (the nation itself being a powerful totem) can be threatened by the creation of supra-national entities and institutions, as has been demonstrated by the demands being made on relatively heavily indebted countries in the eurozone. What Durkheim says of the transterritorial "mythological personages" applies just as well to markets: in pulling national groups under their influence, and dispensing their version of divine economic justice, they "are the great international gods" (Durkheim 1995: 428).

10. For a discussion of Durkheim's relationship to vitalism, see Hirst (1975).

11. Cosmopolitanism is another expression of such "international groupings." See Inglis and Delanty (2010). 
Significantly, it is not only individual market actors who act emotionally: markets themselves are represented, not only as (sometimes) "volatile," but as displaying emotion. ${ }^{12}$ Such discursive representations are the corollary of the objectivation of markets produced by technological developments and found in knowledge production (analysis, charts, predictions, etc.) The market totem thus generates, and is generated by, knowledge and emotion, or ways of acting, thinking and feeling.

The historical development of markets is grounded on and generates values (money, profit, wealth) that prompt actions in support of those values. Ways of acting and thinking in the market include the production of reflexive actor orientations, whereby market actors orient to the objectivation of the market by attending to its signs, but also by trying to forecast its potential directions. Along with the technological developments that make, and continue to make, markets, and which also seek to aid in market forecasting, investors develop strategies to "play" the market and so profit. To provide a simple example, contrarian investor strategies (such as shorting stocks) act against the dominant market actions (the latter sometimes referred to as the "herd"), and thus, not only act against the dominant market sentiments, but require discipline and nerve - the ability to resist powerful market emotions. The "emotionality" of the market may override rational orientations, as in the fear prompted by panics, producing losses and market disasters, or it may provide for the exercise of knowledge and discipline to take advantage of and exploit this emotionality.

Market "emotions" are commonly referred to in business reports and news programs. Markets are characterized as "nervous," "anxious," "jittery," "confident," and "pessimistic" among many other emotion descriptors. They also have "expectations" and can be "disappointed." The following is an example from an article on investing in the Business Section of a national newspaper:

In financial markets where the greatest risk is not earnings or interest rates but confidence itself, investors can be forgiven for feeling nervous. Hope springs eternal, but right now the lust for gains is being countered by fear...Italian bond yields broke through bailout territory of 7 per cent this week, but few were stepping up to buy... The stock market, too is nervous...In financial markets, confidence is everything. Christine Lagarde, head of the International Monetary Fund, warned this week that the world risked a "downward spiral of uncertainty, financial instability and potential collapse of global demand." So what is an investor to do? (Maley 2011: B11)

12. The Chicago Board Options Exchange Market Volatility Index (VIX) measures the implied volatility of S\&P 500 options. It is also known as the "fear index." 
Here, not only are investors nervous but so too are stock markets. The writer certainly lays the emotion adjectives on thickly: hope, lust, fear. However, in financial markets, "confidence is everything" (confidence: con-fidere, with trust; faith). The report provides an account of market actions. The emotion (confidence) is more important than market signifiers, such as earnings and interest rates. These signifiers of market objects are not anything in themselves, or, if they are something, it is through being animated by emotions - such as confidence.

In his discussion of the origin of the totemic principle, Durkheim writes that "collective representations often impute to the things to which they refer properties that do not exist in them in any form or to any degree whatsoever. From the most commonplace object, they can make a sacred and very powerful being. However, even though purely ideal, the powers thereby conferred on the object behave as if they were real" (1995: 229). He further states that "Religious force is none other than the feeling that collectivity inspires in its members, but projected outside the minds that experience them, and objectified. To become objectified, it fixes on a thing that thereby become sacred; any object can play this role...The sacredness exhibited by the thing is not implicated in the intrinsic properties of the thing: It is added to them" (Durkheim 1995: 230).

That markets exist in states of excitation, or that they inspire confidence (or not) is only possible on the basis of collective emotional investments: earnings, interest rates, and stock and financial markets must be sacralised. The "feeling that collectivity inspires in its members... and objectified" is fixed in this case on the market, and this object is talked about and represented as itself generating emotions ("feeling").

One of the emotions invested into markets, and which markets project, is hope. This is demonstrated, not only in the mundane hope that markets will rise rather than fall on any given day, but in the generalized hope of "economic growth" which is a more contemporary expression of Adam Smith's interest in the "wealth of nations." The constant attention paid to markets in television and newspaper reports, not to mention investors who monitor markets for their portfolios, or economists who counsel governments and firms or create policies, signals not only the collective interest and investment in markets but a collective orientation to hope. One term that relates to hope is "bullishness" (e.g., "bull markets") generally referring to a positive feeling about the direction of markets. "Bear" markets connote negative market sentiments, and some market analysts with strongly negative views have been likened to doomsday prophets, such as economist Nouriel Roubini - "Dr. Doom." Generalized hope is in any case manifested through the desire to obses- 
sively monitor and measure market motion, demonstrated every day in the reporting of the "closing numbers" of market indexes. Indeed, this appears as a communion with monetary numbers. The desire is for markets to rise and to confer wealth as mana, or power (Durkheim 1995: 421).

In terms of broader economies, the normative assumption is growth or expansion, and in times of recession and depression, there is the concerned attention to signs of "recovery." The term "Depression" takes on added significance from a Durkheimian perspective: it is typically used to characterize a dire economic condition (no growth, high unemployment, little consumption, etc.) but its reference to an emotional state (sadness, lack of energy, meaninglessness, etc.), in particular, a collective emotional state, is not usually referred to. However, in Suicide, Durkheim documented the links between suicide and financial crises. ${ }^{13}$ Since "the opinions of actors... are treated as social facts of prime importance in the financial market" (Steiner 2009: 87), the "coordination of representations" by experts (Simiand 1937: 28) is an important feature of market action. The unwillingness of economic analysts to use the word "Depression" following the 2008 crisis suggests magical thinking - that uttering it will produce it: in this discussion it speaks to market performativity. ${ }^{14}$

As the primary sociological phenomenon Durkheim formulates in $E F R L$, the totemic principle is the condition of possibility for sustaining the moral authority and basis of a collectivity. The principle makes collective identification (group identity) possible: the collective generates and reproduces itself as collective by differentiating the sacred from the profane, submitting to highly authoritative collective representations, and enacting the sacred through rituals. However, as Durkheim makes clear, the principle also depends upon and generates emotional projection and attachments. This is demonstrated in the various types of rites Durkheim analyzes, e.g., ascetic, mimetic, representative, and piacular (Durkheim 1995: 303-417). If (collective) life, since it is lived in social groups, requires regenerating rituals, it also requires positive emotions. The analysis of the totemic principle uncovers the sociological significance of "confidence": "joyful confidence, rather than terror or

13. See Durkheim's discussion of anomic suicide (1966: 241-258). Suicide rates also increased in times of sudden prosperity.

14. The practices of market performativity are explored in the work of Donald Mackenzie $(2006,2007)$ and Michel Callon (1998, 2007). Market discourse (e.g. "technical recovery," etc.) appears to be a ripe field for sociological analysis (see, e.g., Ailon (2012) for an analysis of the "discursive management of financial risk scandals"). 
constraint, is at the root of totemism" (Durkheim 1995: 225). This does not mean that collectivities do not experience their emotional ups and downs, their "states of collective euphoria and dysphoria" (Durkheim 1995: 417). However, in periods of dysphoria - i.e., in economic recessions, depressions, and crises, it is nevertheless necessary to enact rites that will generate "moral strength and confidence" (Durkheim 1995: 390).

The reference to confidence is common in talk about markets. ${ }^{15}$ Here is another example, from a business article on the "injection of liquidity" into the eurozone:

The ocean of new liquidity gave the banks the ability-and the confidence - to buy sovereign debt in the hopes of making a profit...

(European Central Bank president Mario) Draghi...did say that the loan injections to the banking system "indicate that our non-standard policy measures are providing a substantial contribution to improving the funding situation of banks, thereby supporting financing conditions and confidence.” (Reguly 2012: B1)

Swedberg (2010) argues that the place of confidence in finance has been little studied in economics, and even less in sociology. He comments that while trust has been widely examined in sociology, confidence has not.

Why sociologists have looked at trust but not at confidence is not clear... Confidence... has probably been viewed by sociologists as a psychological phenomenon, just as in economics. And since Durkheim sociologists have tended to stay away from truly psychological phenomena and mainly focus on what takes place outside the individual, as opposed to what happens inside the mind of the individual actor (Swedberg 2010:14).

While Swedberg may be alerting sociologists here to their lapse, or a lack of sociological confidence, he nevertheless does not refer to Durkheim's formulations in his discussion of confidence in the sociological literature. Nor is the Durkheim-inspired work of Simiand on money, confidence, and expectation addressed (Simiand 1934, 1937; Steiner 2008: 142-164). Swedberg (2010: 15-16) refers instead to Weber and Simmel on the phenomenon of trust, thus also bypassing Durkheim's important

15. Renowned American economist Paul Krugman (2012) has made critical comments on the place of confidence in economic policy, referring to the "confidence fairy." On the one hand, as this paper discusses, the understanding of markets can benefit from a sociological analysis of its totemic characteristics, including market emotions. On the other, the critique of confidence could go further, since market confidence also requires its confidence men. 
formulations of trust. Simmel, it appears, offers the most useful conceptions of trust and confidence:

Translators of Simmel's work into English often render the word Vertrauen....as "confidence." But Simmel also used this term for another type of trust: and here the translators use "trust." In the latter case there is something else involved besides knowledge. This something else is "hard to define", but comes to its clearest expression in religious faith... His most precise attempt to define this element can be found in his description of it as an "element of social-psychological quasi-religious faith." (Swedberg 2010: 16)

Further, Simmel also "emphasizes the interactional dimension of trust and confidence more than its psychological and individual dimension. Trust and confidence (Simmel) says, are something that "people have in each other" (Swedberg 2010: 16).

If theorists such as Simmel have been preferred over Durkheim in the analysis of modern market economies, it was Durkheim who theorized the social basis and profound sociological significance of trust through his formulations of precontractual solidarity, "bonds of sympathy," and the collective conscience (Durkheim 1964). While business action generally depends upon trust, it is noteworthy that contemporary enterprises such as ebay (computer mediated buying and selling between strangers) and Grameen Bank (which lends money to impoverished individuals) could not operate without precontractual solidarity (Schachter 2012). Further, the "quasi-religious faith" that defines Simmel's conceptions of trust and confidence would seem to presuppose the totemic phenomena and social practices that Durkheim analyzes in EFRL.

The exceptions to economic sociology's lack of analyses of confidence are those that have sought to "portray trust (and confidence) as an emotion" (Swedberg 2010: 18). Swedberg cites Barbalet (1998) and Pixley (2004) in this regard. In both cases, confidence is conceived as necessarily going beyond the rational (calculation) to embody emotion, since the "future is unknowable" (Swedberg 2010: 18). That confidence should be conceived as an emotion was formulated by Durkheim in EFRL, except that for him it is generated by the totemically-organized collectivity. Swedberg goes on to suggest that:

A solid theory of confidence must also be capable of handling different types of actors. In discussions of confidence and trust, the actor is typically assumed to be an individual. The reason for this is probably that trust and confidence are seen as psychological in nature; and psychology deals with the individual. In the modern economy, however, the main actors are institutions; and trust and confidence have consequently to be theorized in such a way that they cover institutions as well as individuals (2010: 20-21). 
Theorizing must move beyond the psychological and individualistic conceptions of market action discussed earlier, since these largely exclude or fail to explain phenomena that are germane to economic life: market emotions, beliefs, representations and other collectively generated phenomena. How do institutions generate confidence, and how do individuals have confidence in them? With these questions, we move toward, and have never left, the sociological. The absence of interest in confidence in economics and finance provides a sociological opportunity to challenge mainstream economics' focus "on a narrow set of factors that drive economic behaviour" (Swedberg 2010: 2). Curiously, Durkheim is not offered as a resource on the topic of confidence. From a Durkheimian perspective, however, confidence relates to the market as a totemic phenomenon, and markets are founded upon the social fact of money and the collective valorization of wealth.

\section{Dangerous Mana}

If the emergence of markets as "secular" totemic entities generates practices and emotions such as speculation and confidence, their rise to institutional prominence also demonstrates dangers for the solidarity of groups whose collective economic existence depends on their valorization. These dangers echo Schumpeter's (1942) notion of capitalistic "creative destruction," since the (negative) consequences of capitalist processes affect social orders. While markets collectively represent modern economic mana, their history in the twentieth and into the twentyfirst centuries has demonstrated numerous scandals, crises, recessions, depressions and forms of corruption. Focusing on the US, while acknowledging global market interconnectedness, in the two decades prior to 2008 (roughly the period of Alan Greenspan's Chairmanship of the Federal Reserve), there have been frequent and severe financial crises and corporate disasters: the 1987 stock market crash; the Savings and Loan crisis (1989); the Long Term Capital Management debacle (1999); the "dot-com" crash (2000); and the Enron implosion (2001) to name a handful. Marazzi notes that since "1985....there has been a financial and/or monetary crisis, on average, every two and a half years" (2011, 79-80). Post-2008, and excluding the eurozone crisis, there has been the collapse of derivatives broker MF Global, the major trading losses of JP Morgan Chase (estimated to be $\$ 6$ billion US) and the Libor (London Interbank Offered Rate) interest rate manipulations by major banks, this last an indicator of major financial institution corruption. 
Accusations of, and legal battles over, fraud and the misleading of investors have dogged major U.S. banks (e.g. Bank of America, JP Morgan Chase, and Wells Fargo) since the 2008 crisis (Rexrode 2012). These events have all occurred during the ascendancy of market-centered neoliberal economic ideology (Pearce and Tombs 1998; Harvey 2007).

In "free market" discourse, held up by Smith's "invisible hand," markets are rational and thereby solidary for society if allowed to function unobstructedly. In a Durkheimian sense however, this apparent rationality has its limits: market freedom produces dangers and destruction (the freedom of a tyrant), while market emotions suggest the enslavement of the child to their emotions. Critics point out that the neoliberal "market" is an ideal and not a reality, since monopolies often prevent competition, and powerful corporations can afford to not play by the (open market) rules by engaging in collusion and market manipulation (Pearce and Tombs 1998: 17-24). The Libor case exemplifies the extent to which "free market" rhetoric is contradicted by economic realities. Issues for solidarity are thereby raised: inequalities exist within markets, providing some enterprises with the power to manipulate other actors, thus foreclosing on the (presumed) idea of market transparency and rationality. The consequences of these inequalities extend beyond markets to affect everyone directly and indirectly connected to markets - Libor is a case in point as interest rates affect everyone ${ }^{16}$ These inequalities "within" markets have consequences for existing social inequalities and can threaten the sacred status of certain activities and objects - e.g., the pursuit of wealth. Further, market illegalities not only challenge market confidence, they generate social distrust and social volatility - criticism and protest. The dangers to solidarity thus occur, not only due to the material effects of such inequalities, but morally, through the ways in which the social discourses and practices that support sacredness get challenged. This demonstrates a crucial Durkheimian point: any particular form of totemic social organization depends upon the confidence it generates. While this discussion has focused on markets and market confidence, any sacred object (whether, deity, wealth, nationhood, etc.) derives its status from mana: the power to generate and maintain confidence. Confidence is thus related to legitimacy as its emotional basis,

16. Libor sets interest rates on $\$ 300$ trillion worth of contracts globally, from mortgages to interest rate swaps. A class action lawsuit has been filed against a dozen of the world's largest banks (including Barclays PLC and Bank of America) by U.S. homeowners who claim that Libor interest rate manipulations raised the rates on their mortgages between 2000 and 2009 (Globe and Mail 2012). 
and can be depleted or destroyed, creating the conditions for the emergence of new totemic phenomena.

\section{Conclusion}

Durkheim's interest in forms of solidarity prompted concerns about the rise to dominance of economic insitutions in modern society, hence his attention to economic anomie. However, the emergence of markets and the legitimizing of speculation, viewed against Durkheim's concerns about diminishing moral authority in modern life, constitutes a dilemma. With its analyses of totemism and the sacred, The Elementary Forms offered formulations of the social basis of moral authority and the social grounds of classification in the midst of an increasingly economically-oriented society. Since its publication, stock and financial markets have become powerful institutions in the collective life of late modern, capitalist societies. While Durkheim disavowed the (im)morality of the "market society," The Elementary Forms nevertheless provides a framework for thinking about the emergent and totemic features of markets and the market-related phenomena of speculation and confidence. However, markets bring with them dangers for social solidarity, as global market events demonstrate the continuing relevance of Durkheim's sociological-moral concerns. His concerns with economic anomie and diminished moral authority stand as a collective representation of emerging late modern, market-dominated societies. A century after the publication of The Elementary Forms, we are thus still in a "period of transition." And yet, what of the collective effervescence generated in response to global financial market damage? Are the market-Gods growing old or still not fully born?

\section{REFERENCES}

Ailon, Galit. 2012. The Discursive Management of Financial Risk Scandals: The Case of Wall Street Journal Commentaries on LTCM and Enron. Qualitative Sociology 35 (3): 251-270.

Akerlof, George A. and Robert J. Shiller. 2009. Animal Spirits: How Human Psychology Drives the Economy, and Why It Matters for Global Capitalism. Princeton, NJ: Princeton University Press.

Barbalet, Jack. 1998. Emotions, Social Theory and Social Structure. Cambridge: Cambridge University Press.

Basen, Ira. 2011. Economics has met the enemy, and it is economics. The Globe and Mail, October 15, p. F1. 
Baudrillard, Jean. 2003. Simulations. New York: Semiotext(e).

Bay, Thomas. 2010. Finance, Critical Finance Studies, http://www.criticalfinancestudies.org/?page id=4, accessed Feb. 14, 2013.

Benjamin, Walter. 1996[1955] On Some Motifs in Baudelaire. In Illuminations, trans. Harry Zohn, 155-200. New York: Schocken Books.

Callon, Michel. 1998. Introduction: The embeddedness of economics market in economics. in The Laws of the Market, Ed. Michel Callon, 1-57. Oxford: Blackwell Publishers.

Callon, Michel, Yuval Millo, and Fabian Muniesa, Eds. 2007. Market Devices. Oxford: Blackwell Publishers.

Cladis, Mark S. 2005. Beyond Solidarity? Durkheim and twenty-first century democracy in a global age. In The Cambridge Companion to Durkheim, Ed. Jeffrey C. Alexander and Philip Smith, 383-409. Cambridge UK: Cambridge University Press.

Cormack, Patricia. 2002. Sociology and Mass Culture: Durkheim, Mills, and Baudrillard. Toronto: The University of Toronto Press.

Datta, Ronjon Paul. 2008. Politics and Existence: Totems, Dispositifs and Some Striking Parallels between Durkheim and Foucault. Journal of Classical Sociology, 8(2): 283-305.

Deflem, Mathieu. 2003 The Sociology of the Sociology of Money: Simmel and the Contemporary Battle of the Classics. Journal of Classical Sociology, 3(1): 67-96.

Durkheim, Emile. 1886. Les etudes de science sociale. Revue philosophique, Vol. 22: 61-80.

Durkheim, Emile. 1964[1895]. The Division of Labour in Society, trans. George Simpson. New York: The Free Press.

Durkheim, Emile. 1966[1897]. Suicide, trans. John A. Spaulding and George Simpson. New York: The Free Press.

Durkheim, Emile. 1970. Les etudes de sciences sociales. In La science sociale et l'action, Ed. Jean Duvignaud, 184-214. Paris: Presses universaires de France.

Durkheim, Emile. 1973. Moral Education: A Study in the Theory and Application of the Sociology of Education, translated by Everett K. Wilson and Herman Schnurer. New York: The Free Press.

Durkheim, Emile, 1975 [1899]. Concerning the definition of religious phenomena. In Durkheim on Religion, Ed. W.S.F. Pickering, 74-99. London: Routledge.

Durkheim, Emile. 1982(1894). The Rules of Sociological Method, edited by Stephen Lukes, translated by W.D. Halls. New York: The Free Press.

Durkheim, Emile. 1992. Professional Ethics and Civic Morals, translated by Cornelia Brookfield. London: Routledge. 
Durkheim, Emile. 1995(1912). The Elementary Forms of Religious Life, translated by Karen E. Fields. New York: The Free Press.

Fabian, Ann. 1990. Card Sharps, Dream Books \& Bucket Shops: Gambling in $19^{\text {th }}$ Century America. Ithaca, NY: Cornell University Press.

Fama, Eugene 1970. "Efficient Capital Markets: A Review of Theory and Empirical Work." Journal of Finance 25 (2): 383-417

Fox, Justin 2011. The Myth of the Rational Market: A History of Risk, Reward, and Delusion on Wall Street. New York: Harper Business.

Friedman, Milton. 1962. Capitalism and Freedom. Chicago: The University of Chicago Press.

Galbraith, John Kenneth. 1988. The Great Crash: 1929. Boston: Houghton Mifflin Co.

Globe and Mail. 2012. US homeowners file class action suit against big banks over Libor. http://www.theglobeandmail.com/report-on-business/international-business/european-business/us-home-owners-file-class-actionsuit-against-big-banks-over-libor/article4612800/ (Accessed October 15, 2012)

Harvey, David. 2007. A Brief History of Neoliberalism. Oxford: Oxford University Press

Hirst, Paul Q. 1975. Durkheim, Bernard, and Epistemology. London: Routledge.

Inglis, David and Gerard Delanty. 2010. An Overview of the Field of Cosmopolitan Studies. In Cosmopolitanism: Critical Concepts in Sociology, Ed. David Inglis and Gerard Delanty, 1-27. Routledge: London, United Kingdom

Knorr Cetina, Karin. and Urs Bruegger. 2002. "Traders" Engagements With Markets: A Postsocial Relationship. Theory, Culture and Society 19(5-6): 161-185.1

Krippner, G. R. 2005. The Financialization of the American Economy. SocioEconomic Review (3): 173- 208.

Krugma, Paul 2012. Death of a Fairy Tale. http://www.nytimes.com/2012/04/27/ opinion/krugman-death-of-a-fairy-tale.html? r=0 (Accessed October 9, 2012)

Mackenzie, Donald. 2006. An Engine, Not a Camera: Finance Theory and the Making of Markets. Cambridge, MA: MIT Press.

Mackenzie, Donald, Fabian Muniesa and Lucia Siu, Eds. 2007. Do Economists Make Markets?: On The Performativity of Markets. Princeton, NJ: Princeton University Press.

Maley, Dianne. 2011. Investing strategies for uncertain times. The Globe and Mail, November 11, p. B11.

Marazzi, Christian. 2011. The Violence of Financial Capitalism, trans. Kristina Lebedva. Cambridge, MA: MIT Press/Semiotext(e). 
Mauss, Marcel. 1914. Les origins de la notion de monnaie. In Marcel Mauss, Oeuvres Vol.2, 1969, Ed. Victor Karady, 106-112. Paris: Editions de Minuit.

Mauss, Marcel. 1924. Les changes. In Ecrits Politiques, 1997, Ed. Marcel Fournier, 567-664. Paris: Fayard.

Mauss, Marcel. 1954(1925). The Gift: Forms and Functions of Exchange in Archaic Societies. Translated by Ian Cunnison. New York: The Free Press.

Merton, Robert. 1968 (1949). Social Structure and Anomie. In Social Theory and Social Structure, 185-214. New York: The Free Press.

Muller, Jerry Z. 2002. The Mind and the Market: Capitalism in Western Thought. New York: Anchor.

Nelson, Julie A. 2006. Economics for Humans. Chicago: University of Chicago Press.

Orru, Marco. 1987. Anomie: History and Meanings, Boston: Allen and Unwin.

Pearce, Frank and Steve Tombs. 1998. Toxic Capitalism: Corporate Crime and the Chemical Industry. Aldershot: Ashgate.

Pixley, Jocelyn. 2004. Emotions in Finance: Distrust and Uncertainty in Global Markets. Cambridge: Cambridge University Press.

Preda, Alex. 2009. Framing Finance: The Boundaries of Markets and Modern Capitalism, Chicago: University of Chicago Press.

Ramp, William and Kerry Badgley. 2009. "Blood Money": Gambling and the Formation of Civic Morality. In Casino State: Legalized Gambling in Canada, Eds. James F. Cosgrave and Thomas R. Klassen, 19-45. Toronto: University of Toronto Press.

Rawls, Anne Warfield. 1996. Durkheim's Epistemology: The Neglected Argument. The American Journal of Sociology, Vol. 102, No. 2: 430-482.

Reguly, Eric. 2012. "EU cheered by success of bond auctions," The Globe and Mail, January. 13.

Rexrode, Christina. 2012. For U.S. banks, long shadow of financial crisis still haunts, The Globe and Mail, p. B8, October 12.

Schachter, Harvey. 2012 The Business Case for Trust. The Globe and Mail, http://www.theglobeandmail.com/report-on-business/careers/management/morning-manager/the-business-case-for-trust/article2321410/ (accessed Feb. 1 (2012)

Schumpeter, Joseph A. 1942(1994). Capitalism, Socialism and Democracy. London: Routledge.

Shiller, Robert J. 2000. Irrational Exuberance. Princeton NJ: Princeton University Press.

Simiand, Francois. 1934. La monnaie, realite sociale. Annales sociologiques, series D, 1: 1-86. 
Simiand, Francois. 1937. La psychologie sociale des crises et des fluctuations de courte duree. In Annales sociologiques, series D, 2: 3-32.

Simmel, Georg. 1971. Fashion. In On Individuality and Social Forms, Ed. Donald N. Levine, 294-323. Chicago: University of Chicago Press.

Simmel, Georg. 1978. The Philosophy of Money, trans. Tom Bottomore and David Frisby. London: Routledge and Kegan Paul.

Simmel, Georg. 1997(1896). Money in Modern Culture. In Simmel on Culture, Eds. David Frisby and Mike Featherstone, 243-255. London: Sage.

Slater, Don and Fran Tonkiss. 2001. Market Society: Markets and Modern Social Theory. Oxford: Polity Press.

Steiner, Philippe. 2008. Durkheim and the Birth of Economic Sociology, trans. Keith Tribe. Princeton: Princteon University Press.

Stewart, Heather 2009 This is how we let the credit crunch happen, Ma'am. http://www.guardian.co.uk/uk/2009/jul/26/monarchy-credit-crunch, (accessed October 9, 2012)

Swedberg, Richard. 2010. The Role of Confidence. Center for The Study of Economy \& Society, Working Paper Series, Paper \#54. Cornell University, Ithaca, NY.

Swedberg, Richard and Mark Granovetter, Eds. 2011. The Sociology of Economic Life, $3^{\text {rd }}$ ed. Boulder, CO: Westview Press.

Thaler, Richard J. 1993. Advances in Behavioural Economics. New York: Russell Sage Foundation.

Thrift, Nigel. 2005. Knowing Capitalism. London: Sage.

Tilman, Rick. 2007. Thorstein Velben and the Enrichment of Evolutionary Naturalism. St. Louis: University of Missouri Press.

Tognato, Carlo. 2007. On the Cultural Macro-Embeddedness of Money and

Central Banking: A neo-Durkheimian Perspective. Working Paper, Center for Cultural Sociology, Yale University, May $13^{\text {th }}$.

Veblen, Thorstein. 1899 [1994]. The Theory of the Leisure Class. New York: Penguin.

Weber, Max. 1958. The Protestant Ethic and the Spirit of Capitalism, trans. Talcott Parsons. Charles Scribner's Sons.

Weber, Max. 2000a (1894). Stock and Commodity Exchanges. Theory and Society (29): 305-338.

Weber, Max. 2000b (1894). Commerce on the Stock and Commodity Exchanges. Theory and Society (29): 339-371. 


\section{ACKNOWLEDGEMENTS}

The author would like to thank the anonymous reviewers for their helpful criticisms and suggestions, and the Special Issue editors for their editorial comments on improving the paper. Special thanks also to Vinciane Boudonnet at Trent University Durham for translation, Frank Pearce for pointing me in the direction of some critical resources, and Patricia Cormack for her engaged reading of drafts of the article.

James F. Cosgrave is an assistant professor in the Department of Sociology at Trent University. His research interests include examination of the state's role in gambling markets, state/culture dynamics and Canadian cultural identity, and the sociology of money and financial markets. Recent publications include "Embedded Addiction: The Social Production of Gambling Knowledge and the Development of Gambling Markets," Canadian Journal of Sociology 2010, 35(1):113-134, and with Patricia Cormack, Desiring Canada: CBC Contests, Hockey Violence, and Other Stately Pleasures, University of Toronto Press.

E-Mail: jimcosgrave@trenu.ca 